\title{
Epilepsy in Mitochondrial Diseases-Current State of Knowledge on Aetiology and Treatment
}

\author{
Dorota Wesół-Kucharska $^{1}$ (D), Dariusz Rokicki ${ }^{1}$ (D) and Aleksandra Jezela-Stanek ${ }^{2, *}$ (D) \\ 1 Department of Pediatrics, Nutrition and Metabolic Diseases, The Children's Memorial Health Institute, Al. \\ Dzieci Polskich 20, 04730 Warsaw, Poland; d.wesol-kucharska@ipczd.pl (D.W.-K.); d.rokicki@ipczd.pl (D.R.) \\ 2 Department of Genetics and Clinical Immunology, National Institute of Tuberculosis and Lung Diseases, \\ 26 Plocka Str, 01138 Warsaw, Poland \\ * Correspondence: jezela@gmail.com
}

Citation: Wesół-Kucharska, D.;

Rokicki, D.; Jezela-Stanek, A. Epilepsy in Mitochondrial Diseases-Current State of Knowledge on Aetiology and Treatment. Children 2021, 8, 532 https://doi.org/10.3390/ children 8070532

Academic Editors: Marco Carotenuto and Maurizio Elia

Received: 18 May 2021

Accepted: 18 June 2021

Published: 22 June 2021

Publisher's Note: MDPI stays neutral with regard to jurisdictional claims in published maps and institutional affiliations.

Copyright: (c) 2021 by the authors. Licensee MDPI, Basel, Switzerland. This article is an open access article distributed under the terms and conditions of the Creative Commons Attribution (CC BY) license (https:// creativecommons.org/licenses/by/ $4.0 /)$.

\begin{abstract}
Mitochondrial diseases are a heterogeneous group of diseases resulting from energy deficit and reduced adenosine triphosphate (ATP) production due to impaired oxidative phosphorylation. The manifestation of mitochondrial disease is usually multi-organ. Epilepsy is one of the most common manifestations of diseases resulting from mitochondrial dysfunction, especially in children. The onset of epilepsy is associated with poor prognosis, while its treatment is very challenging, which further adversely affects the course of these disorders. Fortunately, our knowledge of mitochondrial diseases is still growing, which gives hope for patients to improve their condition in the future. The paper presents the pathophysiology, clinical picture and treatment options for epilepsy in patients with mitochondrial disease.
\end{abstract}

Keywords: epilepsy; mitochondrial disorders; mtDNA; nDNA; treatment; antiepileptic drugs (AED)

\section{Introduction}

Mitochondria are organelles that are present in almost all cells of the body, which are primarily responsible for producing energy (in the form of ATP) by the process of oxidative phosphorylation (OXPHOS), play a role in the homeostasis of calcium ions, take part in signal transduction between cells by producing reactive oxygen species, and also participate in cell apoptosis [1,2]. Mitochondrial diseases (MDs) represent a clinically and genetically heterogeneous group of diseases with a summary incidence estimated at 1.6:5000 live births, making them the most common diseases among inherited metabolic diseases [2,3]. The diseases may result both from a pathogenic variant in all 37 genes of mitochondrial DNA (mtDNA) and damage to nuclear DNA (nDNA). Currently, almost 400 genes related to MD are identified in nDNA [2,4,5]. The clinical picture of MD is very varied, but typically the highly energetic tissues are affected, including the central and peripheral nervous system, skeletal muscles, sense organs, heart, liver, gastrointestinal tract, or endocrine system $[2,4,5]$. Central nervous system symptoms-regression in development, delayed psychomotor development, or epilepsy—are dominant features in children with MD. Epilepsy is nonetheless a most clinically significant problem among MD patients since seizures are usually difficult to treat and often deteriorate the patient's cognitive development, leading to epileptic encephalopathy or a worse prognosis. The incidence rate of epileptic seizures among MD subjects is estimated at $10-40 \%$, but it may even reach $60 \%$ in paediatric patients [6-10].

\section{Pathophysiology of Epilepsy in Mitochondrial Diseases}

Epileptic seizure is a sudden and excessive neural discharge resulting from uncontrolled depolarisation of the neural membrane, and its spread is caused by impaired mechanisms regulating this transmission, e.g., balance between inhibitory $(\gamma$-aminobutyric 
acid, GABA) and stimulatory (glutamic and aspartic acid) neurotransmitters. Maintaining membrane polarisation requires high energy input and primarily involves calcium and sodium channels [11]. The pathophysiology of epilepsy in MD is not fully known (Figure 1).

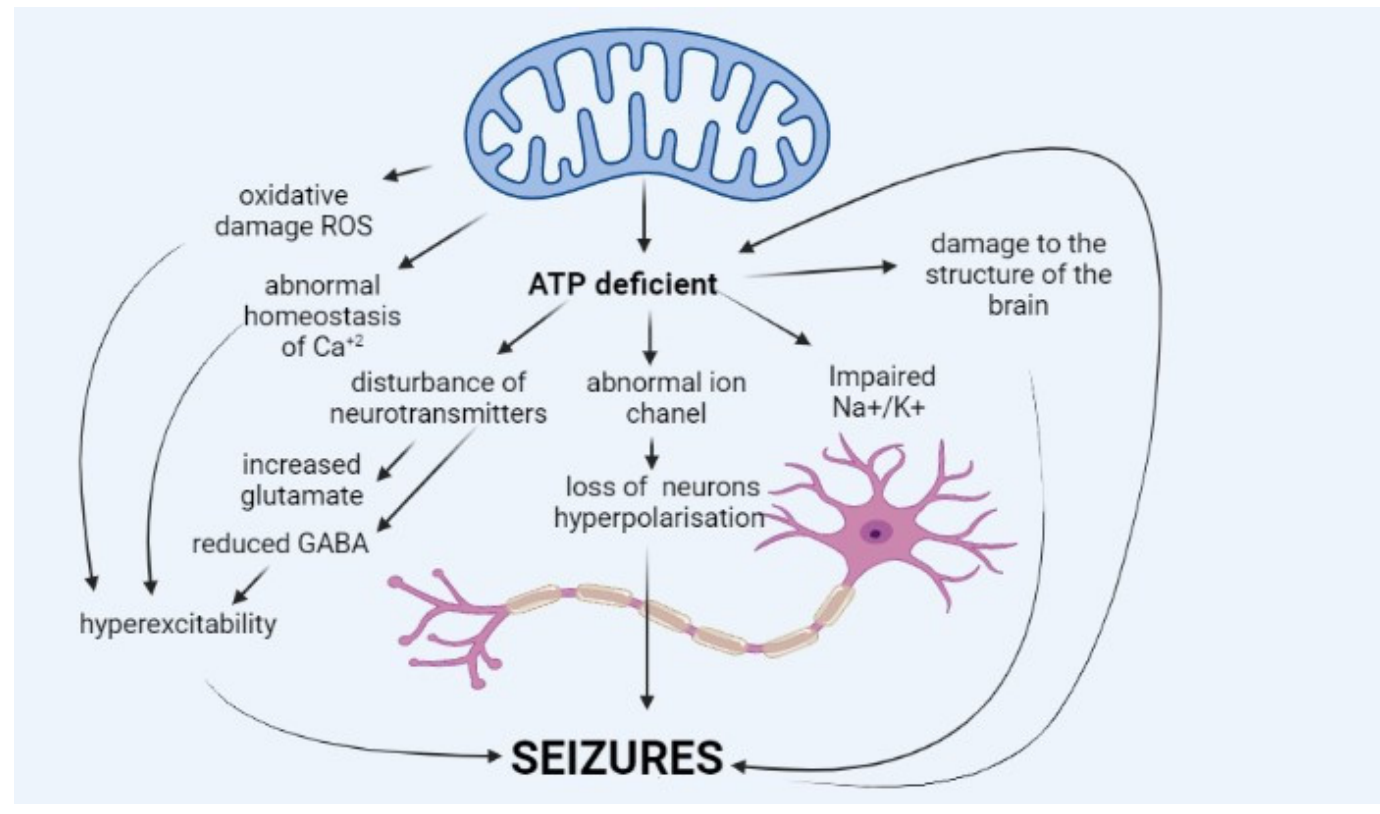

Figure 1. Pathophysiology of epilepsy in mitochondrial diseases. (GABA: $\gamma$-aminobutyric acid, $\mathrm{Na}+/ \mathrm{K}+$ : sodium-potassium ATPase, ROS: reactive oxygen species).

The occurrence of seizures is explained mainly by a deficit of energy, ATP, resulting from impaired oxidative phosphorylation, which is the core of MD. ATP molecules are of key importance for the function of sodium-potassium ATPase ( $\mathrm{Na}+\mathrm{K}+$ ATPase), which ensures normal polarisation of the neural membrane and maintenance of resting membrane potential. Impairment in the potential leads to neuronal hyperexcitability, which translates into seizures.

Additionally, ATP deficit suppresses the effect of intermediate inhibitory neurons in the hippocampus, facilitating the spread of excitation in the neuronal network $[6,12,13]$. Lack of ATP molecules also results in the reduced potential of GABA-ergic inhibitory neurons, which leads to an impaired balance between excitatory and inhibitory neurons and excessive cell excitation [13,14]. Moreover, ATP deficit leads to increased glutamate release (excitatory neurotransmitter) from astrocytes to synaptic space and disturbance of the glutamate-aspartate transporter $[1,13,15]$. Other hypotheses explain seizures in MD by abnormal haemostasis of calcium ions, abnormal function of ion channels in the neural membrane, or neurotransmitter disorders [15]. A growing amount of data suggest that seizures occurring in MD patients may be caused by excessive amounts of reactive oxygen species (ROS), resulting from abnormal mitochondrial function $[1,16,17]$. Seizures occurring in the course of mitochondrial diseases may also have a structural background. Severe forms of pyruvate dehydrogenase complex (PDHc) deficit involve damage to the brain structure as early as in the intrauterine stage, which may be the source of seizure [18].

Moreover, the seizures themselves, especially those that are repeated or long-lasting, lead to mitochondrial dysfunction and escalate energy deficit (epileptic seizures use large amounts of energy), which provokes subsequent seizures and makes them difficult to suppress. Such a self-perpetuating cycle may lead to the development of stroke-resistant episodes common in MD, especially in mitochondrial encephalopathy, lactic acidosis, and stroke-like episodes (MELAS) and POLG-related diseases (diseases resulting from damage 
to DNA polymerase gamma), and the occurrence of such episodes is often related to status epilepticus [8,15].

Although the pathomechanism of epilepsy in MD patients mentioned above seems probable, this does not explain why seizures only occur in some MD patients. Additionally, there are changes in mtDNA (especially with variants $\mathrm{m} .3243 \mathrm{~A}>\mathrm{G}$ and $\mathrm{m} .8344 \mathrm{~A}>\mathrm{G}$ ) and nDNA (e.g., mutations in POLG) which predispose to the development of epilepsy. The exact phenotypic manifestation is, however, difficult to predict (see Table 1). The degree of heteroplasmy explains only to some extent the severity of mitochondrial diseases. Moreover, as supported by Tranah et al., the accumulation of a rare genetic disease mutation, e.g., m.3243A $>\mathrm{G}$, manifests as several ageing outcomes, and some diseases of ageing may be attributed to the accumulation of mtDNA damage, leading to differing phenotypes [19]. Additionally, seizures are more common in complex I and/or IV of mitochondrial respiratory chain failures than in complex II and III [9,10,20-22]. On the other hand, it was observed that $\mathrm{MD}$, depending on changes in specific genes (e.g., SURF1, OPA1, PEO1, m.14709), does not involve epileptic seizures, and the pathomechanism of this phenomenon is not known $[8,22,23]$. Finally, the role of other genetic variants or polymorphism has to be defined. As discussed by Pickett et al., age, age-adjusted blood heteroplasmy levels, and sex are poor predictors of phenotypic severity. Still, the provided results showed good evidence for the presence of nuclear genetic factors influencing clinical outcomes in m.3234A>G-related disease [24].

Table 1. The most frequent mitochondrial diseases with epilepsy (causative genetic variants are cited from OMIM database, https:/ / www.omim.org and MITOMAP, https:/ /www.mitmap.org/ MITOMAP, accessed 2 June 2021).

\begin{tabular}{|c|c|c|c|}
\hline Disease & Gene & Clinical Picture & Treatment \\
\hline $\begin{array}{c}\text { Alpers- } \\
\text { Huttenlocher } \\
\text { syndrome (AHS) } \\
{[25,26]}\end{array}$ & POLG (nDNA) & $\begin{array}{l}\text { Progressive neurodegeneration, } \\
\text { refractory seizures, movement } \\
\text { disorder, neuropathy and } \\
\text { hepatic failure, focal-onset } \\
\text { seizures predominate, but } \\
\text { seizure may also tonic-clonic, or } \\
\text { myoclonic; } 68 \% \text { developed status } \\
\text { epilepticus and } 58 \% \text { epilepsia } \\
\text { partialis continua, status } \\
\text { epilepticus is the leading cause } \\
\text { of death in children with AHS }\end{array}$ & $\begin{array}{c}\text { In case of } \\
\text { refractory } \\
\text { seizures, } \\
\text { polytherapy is } \\
\text { necessary (with } \\
\text { no dedicated } \\
\text { drug; however, } \\
\text { valproic acid is } \\
\text { absolutely } \\
\text { contraindicated) }\end{array}$ \\
\hline $\begin{array}{c}\text { Pyruvate } \\
\text { dehydrogenase } \\
\text { complex deficiency } \\
(\text { PDHc) } \\
{[27,28]}\end{array}$ & $\begin{array}{l}\text { PDHA, PDHB, } \\
\text { LIAS, LIPT1, } \\
\text { DLD, PDH, } \\
\text { (nDNA) }\end{array}$ & $\begin{array}{l}\text { Epilepsy begins in infancy with } \\
\text { infantile spasms, clonic seizures } \\
\text { or refractory focal epilepsy, } \\
\text { developmental delay, ataxia, } \\
\text { hypotonia, hypertonia, abnormal } \\
\text { eye movements, dystonia, } \\
\text { axonal neuropathy }\end{array}$ & $\begin{array}{l}\text { The ketogenic diet } \\
\text { is the treatment of } \\
\text { choice; in some } \\
\text { individuals, } \\
\text { improvement } \\
\text { after thiamine } \\
\text { supply possible }\end{array}$ \\
\hline $\begin{array}{l}\text { Leigh syndrome } \\
\text { (LS) } \\
{[29]}\end{array}$ & $\begin{array}{l}\text { More than } 90 \\
\text { genes (nDNA } \\
\text { and mtDNA) }\end{array}$ & $\begin{array}{l}\text { Typical features include: }(1) \\
\text { developmental regression or } \\
\text { developmental delay, (2) specific } \\
\text { basal ganglia/brain stem } \\
\text { changes bilaterally, and (3) } \\
\text { abnormal mitochondrial energy } \\
\text { metabolism; epileptic seizures } \\
\text { are frequent, both focal } \\
\text { and generalised }\end{array}$ & $\begin{array}{l}\text { Due to frequent } \\
\text { drug-refractory } \\
\text { seizures, } \\
\text { polytherapy is } \\
\text { often necessary }\end{array}$ \\
\hline
\end{tabular}


Table 1. Cont.

\begin{tabular}{|c|c|c|c|}
\hline Disease & Gene & Clinical Picture & Treatment \\
\hline $\begin{array}{c}\text { Myoclonic epilepsy } \\
\text { with ragged red } \\
\text { fibres (MERRF) } \\
{[30,31]}\end{array}$ & $\begin{array}{c}\text { The most } \\
\text { common } \\
\text { pathogenic } \\
\text { variants in } \\
\text { mtDNA, MTTL1 } \\
(80 \%): \\
\text { m.8344A }>\mathrm{G} ; \\
\text { MTTK }(10 \%): \\
\mathrm{m} .8356 \mathrm{~T}>\mathrm{C} \\
\mathrm{m} .8363 \mathrm{G}>\mathrm{A} \\
\mathrm{m} .8361 \mathrm{G}>\mathrm{A}\end{array}$ & $\begin{array}{l}\text { Onset usually in adults, } 30 \% \text { in } \\
\text { childhood. Progressive } \\
\text { myoclonic epilepsy is part of the } \\
\text { phenotype, but seizures can be } \\
\text { often generalised tonic, clonic or } \\
\text { atonic. Seizure was reported in } \\
33 \% \text { to } 100 \% \text { of patients; } \\
\text { co-occurs with cerebellar ataxia, } \\
\text { cardiac arrhythmias, myopathy, } \\
\text { diabetes, hearing loss, dementia }\end{array}$ & $\begin{array}{l}\text { The combination } \\
\text { of levetiracetam } \\
\text { with } \\
\text { carbamazepine } \\
\text { may have the } \\
\text { strongest } \\
\text { beneficial effect } \\
\text { on myoclonic } \\
\text { seizures }\end{array}$ \\
\hline $\begin{array}{c}\text { Mitochondrial } \\
\text { encephalopathy, } \\
\text { lactic acidosis, and } \\
\text { stroke-like episodes } \\
\text { (MELAS) } \\
\text { [32] }\end{array}$ & $\begin{array}{l}\text { The most } \\
\text { common } \\
\text { pathogenic } \\
\text { variants in } \\
\text { mtDNA, } \\
\text { MTTL1 gen: } \\
\text { m.3243A >G } \\
\text { m.3271T }>\text { C; } \\
\text { MTND5 gen: } \\
\text { m.13513G }>\text { A }\end{array}$ & $\begin{array}{l}\text { Focal and generalised seizures } \\
\text { are possible, preceded by or } \\
\text { associated with migraine-like } \\
\text { headache; the most typical are } \\
\text { seizures in the course of a } \\
\text { stroke-like episode, focal status } \\
\text { epilepticus with a secondary } \\
\text { encephalopathy is common }\end{array}$ & $\begin{array}{l}\text { L-arginine and/or } \\
\text { citrulline as } \\
\text { prevention and } \\
\text { treatment of } \\
\text { stroke-like } \\
\text { episodes }\end{array}$ \\
\hline
\end{tabular}

\section{Clinical Picture of Epilepsy in Mitochondrial Diseases}

The onset of seizures in MD patients may occur at any age. Seizures may be one of the first symptoms of mitochondrial disease in children (in nearly 20\%), but in most patients, they occur as the disease progresses and changes in the central nervous system (CNS) become more severe, e.g., in the course of recurrent stroke-like episodes, or with the progression of other neurodegenerative changes [23]. Typically, epilepsy is one of many other MD symptoms, and it is the most common feature of CNS involvement $[8,33]$. In certain mitochondrial diseases, seizures are part of a syndrome-e.g., in Alpers-Huttenlocher syndrome (AHS) and other phenotypes associated with a pathogenic variant in the POLG gene, in a deficit of pyruvate dehydrogenase complex (PDHc), myoclonic epilepsy with ragged red fibres (MERRF), MELAS, or in Leigh syndrome. A short characterisation of the diseases mentioned above is presented in Table 1 [25-32].

In patients showing epilepsy in the course of MD, the onset of the disease's symptoms occur much earlier than in subjects without seizures. Patients with MD and epilepsy more often presented perinatal symptoms (e.g., disorders in the intrauterine development or hypertrophic cardiomyopathy) and delayed or impaired development than subjects without epilepsy [8-10].

MD patients most often experience myoclonus and various types of focal seizures, but the seizure may also have any other morphology: tonic seizures, tonic-clonic seizures, infantile spasms, or even, occasionally, typical absence seizures. From $20-60 \%$ of patients experience various types of seizures [4,8-10]. Epileptic seizures may form specific epilepsy syndromes-such as West syndrome, Ohtahara syndrome, Lennox-Gastaut syndrome, and Landau-Kleffner syndrome $[9,20,23,33]$. In the majority of patients $(>92 \%)$, seizures frequently recur, and in $27 \%$, their occurrence is considered very frequent (every day or every week) [10].

Aside from refractory and frequently recurring seizures, MD patients experience status epilepticus, including nonconvulsive status epilepticus and epilepsia partialis continua (EPC) - a focal motor status epilepticus (spontaneous regular or irregular clonic muscular twitching affecting a limited part of the body, sometimes aggravated by action or sensory stimuli, occurring for a minimum of one hour, and recurring at intervals of no more than ten seconds) [34]. They are difficult to diagnose and treat, thus resulting in a poor prognosis. 
Status epilepticus in MD is more common in patients with damage to mtDNA (especially in MELAS and MERRF syndromes) and mitochondrial depletion syndromes (especially with pathogenic changes in POLG) and are co-existent with stroke-like episodes [1,25,26,32,35]. EPC has been observed in subjects with pathogenic variants in POLG and mtDNA. In addition, this may be the first epilepsy manifestation in these subjects. EPC is related to a very poor prognosis-out of 12 paediatric patients with MD and EPC, in only two patients were the seizures partially controlled, in 2/12 disease progression occurred, and 8/12 died within a year of the EPC episode [34].

\section{Diagnostics of Epilepsy in Mitochondrial Disease}

\subsection{Electroencephalography in Patients with Mitochondrial Disease}

There is no typical EEG trace for seizures in MD. Background activity in most patients, even without clinical symptoms, is disturbed: 109/165 (66\%) of patients had abnormal EEG, mainly in the form of slow background activity with a large proportion of delta waves and lack of spatial differentiation or trace asymmetry $[9,21]$. Epileptiform changes in EEG of MD subjects typically involve focal changes (23-71\%) and multifocal changes (35-56\%), sometimes generalised changes (13-25\%), or hypsarrhythmia [36,37]. Most frequently, seizures are propagated from the occipital lobe and posterior quadrant of temporal and parietal lobes. Myoclonic seizures involve spikes and polyspikes, which may be activated by photostimulation or opening of the eyes. However, it must be remembered that such seizures, especially in MERRF, are not always caused by epileptic activity, but they may result from cerebellar or medullary dysfunction [15,35]. On the other hand, Alpers-Huttenlocher syndrome typically involves occipital rhythmic high-amplitude delta with superimposed (poly)spikes (RHADS), but this is not a pathognomonic trace for this syndrome only [38]. About $10 \%$ of MD patients show normal EEG despite epileptic seizures; however, these are patients with occasional seizures [10].

\subsection{Neuroimaging}

Neuroimaging changes in MD are quite characteristic for this group of patients, but they are not recognisable. MD's typical features include bilateral symmetrical signal abnormality in the basal ganglia, brain stem, thalamus, and/or cerebellum hyperintensities in T2 and FLAIR $[4,8,21]$. White matter may be diffusely abnormal (leukodystrophy) $[8,20]$. There may also be structural brain abnormalities like agenesis of the corpus callosum, and ventriculomegaly as an effect of energy deficiency during brain formation [29]. A definite lactate peak is observed in MD by proton MR spectroscopy [21]. The analysis of 1467 patients with MD revealed that MRI abnormalities were significantly more common $(p<0.001)$ in subjects with epilepsy than in MD patients without seizures (88 vs. 54\%) [10]. Brain atrophy was also more common in the group of epileptic subjects [36,38]. Moreover, patients with MD and epilepsy most often report stroke-like changes, as well as changes in basal ganglia and white matter $[33,36]$.

\section{Pharmacological Treatment of Epilepsy in Patients with Mitochondrial Disease}

Treatment of mitochondrial disorders is a challenge for physicians and researchers. Most interventions and guidelines are related to symptomatic treatment, with supplementation of cofactors, vitamins, or antioxidants, and mild exercises are recommended. Despite numerous studies, the efficacy of most of these interventions has not been confirmed [39-43].

There is also no established scheme of epilepsy treatment in mitochondrial diseases; therefore, general principles of epilepsy treatment are applied [44]. First-line therapy often includes levetiracetam (LEV), frequently combined with clonazepam (CZP), clobazam (CLB), or topiramate (TPM). Zonisamide (ZNS) is also safe, but there are few literature reports of patients treated with this medication [31,35,45]. Lamotrigine (LTG) may promote myoclonic seizures and has not always been effective in patients with MD. Some experts recommend phenobarbital $(\mathrm{PB})$ or primidone (PRM), but there are few studies on the use of these drugs, and not all of them showed efficacy [35]. There are also reports on perampanel 
(PER) efficacy in treating status epilepticus in subjects with MELAS [46]. In most patients, seizures are intractable, which often require polytherapy with two or three medications. Only $5-30 \%$ of patients had seizures controlled with one antiepileptic drug only. In nearly $8 \%$ of patients, it was possible to discontinue treatment $[8,33]$.

Treatment of status epilepticus is also challenging. The management of MD patients is similar to the management of status epilepticus in other patients, except for avoiding the administration of valproic acid. First-line therapy includes benzodiazepines-e.g., midazolam and LEV (20-40 mg/ $\mathrm{kg}$, $\max 4500 \mathrm{mg}$ ) intravenous (iv), but the use of phenytoin $(15-20 \mathrm{mg} / \mathrm{kg})$, phenobarbital $(10-15 \mathrm{mg} / \mathrm{kg})$, or lacosamide $(200-400 \mathrm{mg})$ is also possible. One must bear in mind that MD patients are more susceptible to the development of propofol infusion syndrome. Although propofol is not contraindicated in patients with $\mathrm{MD}$, caution is recommended while using this drug in this group of subjects $[15,47,48]$.

Regarding contraindicated substances, the only absolutely contraindicated drug in treating epilepsy in MD patients is valproic acid (VPA), which is especially relevant for diseases associated with POLG pathogenic variants. The drug may induce fulminant hepatic impairment in these subjects $[25,49]$. Additionally, VPA may cause secondary carnitine deficit, especially in patients with damage to complex I and IV of the mitochondrial respiratory chain [6]. There are single reports of successful VPA treatment of epilepsy in subjects with mitochondrial disease. However, caution is always recommended before introducing this drug in patients with suspected MD [36,39]. Experts suggest VPA in MD patients without a pathogenic variant in $P O L G$, and without liver disease, for the treatment of refractory epilepsy [47]. In patients with mitochondrial depletion syndrome, one should avoid the use of vigabatrin (VGB), which inhibits the conversion of deoxyribonucleoside diphosphate (ADP) to deoxyribonucleoside triphosphate (ATP), whereby it increases mtDNA depletion. When using topiramate (TPM), it must be remembered that it potentiates acidosis [39]. On the other hand, the toxicity of carbamazepine (CBZ), phenytoin (PHT), or phenobarbital (PB) outweighs their efficacy, so these agents should be avoided in the treatment of MD patients [50]. A list of safe antiepileptic drugs which may be used in patients with mitochondrial disease is presented in Table 2.

Table 2. Safety of antiepileptic drugs in mitochondrial diseases.

\begin{tabular}{ccc}
\hline Mitochondria-Safe AEDs & AEDs to Use Carefully & $\begin{array}{c}\text { AEDs Which Could } \\
\text { Aggravate Myoclonus }\end{array}$ \\
\hline Benzodiazepine [47,51] & Valproic acid-contraindicated in & Valproic acid [35] \\
Gabapentin [47,51] & POLG mutations [25,39,51] & Phenobarbital [35] \\
Lacosamide [47,51] & Vigabatrin-may need to be & Lamotrigine [35] \\
Lamotrigine [47,51] & avoided in patients with mtDNA & Phenytoin [35] \\
Levetiracetam [10,47,51] & depletion syndromes [39] & Carbamazepine [35] \\
Oxcarbazepine [10,47,51] & Topiramate-may worsen & Oxcarbazepine [35] \\
Peranpanel [46,47,51] & acidosis [39] & Vigabatrin [35] \\
Rufinamide [47,51] & Phenytoin * [50] & Tiagabine [35] \\
Stiripentol [10,47,51] & Carbamazepine * [50] & Gabapentin [35] \\
Zonisamide [47,51] & Phenobarbital * [50] & Pregabalin [35] \\
\hline * Toxic effect on mitochondria outweighs the beneficial effect.
\end{tabular}

In patients with the m.3243A $>\mathrm{G}$ variant, the administration of L-arginine has been confirmed to reduce the incidence of stroke-like episodes and thus reduce the risk of epilepsy and status epilepticus in the course of such episodes [52]. There are also single reports in subjects with epilepsy and Kearns-Sayre syndrome diagnosed with folate (5methyltetrahydrofolate) deficit, where folic acid supplementation in these subjects was related to improvement in seizure control [53]. Next, high doses of co-enzyme Q10 in patients with primary co-enzyme Q10 deficiency may reduce epileptic seizures in this group of subjects [35]. 
MD therapy must not exclude such diseases, where it is possible to apply causal treatment or at least mitigation of disease symptoms. Examples of such conditions with specific procedures are presented in Table 3.

Table 3. Currently available treatment options in mitochondrial diseases.

\begin{tabular}{|c|c|c|}
\hline $\begin{array}{l}\text { Disease } \\
\text { (Gene) }\end{array}$ & Clinical Features & Treatment \\
\hline $\begin{array}{c}\text { Primary co-enzyme } \mathrm{Q}_{10} \\
\text { deficiency }(\mathrm{COQ} 2, \mathrm{COQ4} \\
\text { COQ5, COQ6, COQ7,COQ9, } \\
\text { PDSS1, PDSS2) }\end{array}$ & $\begin{array}{c}\text { Multisystem involvement with progressive neurological } \\
\text { dysfunction, seizures, encephalopathy, stroke-like episodes, } \\
\text { cerebellar ataxia, pyramidal dysfunction, cognitive } \\
\text { impairment renal failure, and steroid-resistant } \\
\text { nephrotic syndrome }\end{array}$ & $\begin{array}{l}\text { High-dose oral } \mathrm{CoQ}_{10} \\
\text { supplementation (ranging from } \\
5 \text { to } 50 \mathrm{mg} / \mathrm{kg} / \text { day) [54] }\end{array}$ \\
\hline $\begin{array}{l}\text { Pyruvate dehydrogenase } \\
\text { complex (PDHc) deficiency } \\
(P D H A 1, P D H B, L I A S, P D P 1 \\
\text { PDHX, DLAT) }\end{array}$ & $\begin{array}{c}\text { Epilepsy, developmental delay, ataxia, hypotonia, } \\
\text { hypertonia, abnormal eye movements, dystonia, ataxia, } \\
\text { axonal neuropathy, and poor feeding }\end{array}$ & $\begin{array}{l}\text { Ketogenic diet 3:1-4:1 and } \\
\text { thiamine }(50 \mathrm{mg} / \mathrm{kg} / \text { day, } \max \\
\text { 300-900 } \mathrm{mg} / \text { day) }[18,27]\end{array}$ \\
\hline $\begin{array}{l}\text { ACAD9 deficiency } \\
\quad(A C A D 9)\end{array}$ & $\begin{array}{l}\text { Hypertrophic cardiomyopathy, lactic acidosis, exercise } \\
\text { intolerance, and occasional seizures }\end{array}$ & $\begin{array}{l}\text { Riboflavin (vitamin B2) } \\
20 \mathrm{mg} / \mathrm{kg} / \text { day-max } 400 \mathrm{mg} / \text { day } \\
\text { [55] }\end{array}$ \\
\hline $\begin{array}{l}\text { Impairment of thiamine } \\
\text { transport and metabolism } \\
\text { (SLC19A3, SLC19A2, } \\
\text { SLC25A19, TPK1) }\end{array}$ & $\begin{array}{l}\text { Biotin-thiamine-responsive basal ganglia disease or Leigh } \\
\text { syndrome; subacute encephalopathy with confusion, } \\
\text { dysphagia, dysarthria, seizures, external ophthalmoplegia, } \\
\text { and generalised stiffness following a history of febrile } \\
\text { illness; progresses to severe quadriparesis, rigidity, dystonia, } \\
\text { coma, and death if early treatment is not administered }\end{array}$ & $\begin{array}{c}\text { Biotin }(5-10 \mathrm{mg} / \mathrm{kg} / \text { day }) \text { and } \\
\text { thiamine }(10-40 \mathrm{mg} / \mathrm{kg} / \text { day, } \\
\text { between } 300 \text { and } 900 \mathrm{mg} / \text { day }) \\
{[56]}\end{array}$ \\
\hline $\begin{array}{l}\text { AGC1 deficiency } \\
\text { (aspartate-glutamate carrier } \\
\text { isoform 1) (SLC25A12) }\end{array}$ & $\begin{array}{c}\text { Severe hypotonia, arrested psychomotor development, and } \\
\text { seizures from a few months of age, a global lack of } \\
\text { myelination in the cerebral hemispheres }\end{array}$ & Ketogenic diet 3:1-4:1 [57] \\
\hline $\begin{array}{l}\text { Ethylmalonic encephalopathy } \\
\text { (ETHE1) }\end{array}$ & $\begin{array}{l}\text { Early onset, progressive disorder, developmental delay, } \\
\text { generalised infantile hypotonia that evolves into hypertonia, } \\
\text { spasticity and dystonia; generalised tonic-clonic seizures; } \\
\text { and generalised microvascular damage }\end{array}$ & $\begin{array}{l}\mathrm{N} \text {-acetylcysteine in combination } \\
\text { with metronidazole [58] }\end{array}$ \\
\hline $\begin{array}{l}\text { Beta-hydroxyisobutyryl-CoA } \\
\text { deacylase deficiency } \\
(H I B C H D)\end{array}$ & $\begin{array}{c}\text { Progressive neurodegenerative disorder, associated with } \\
\text { basal ganglia changes on brain magnetic resonance imaging; } \\
\text { elevated hydroxy-C4-carnitine levels }\end{array}$ & $\begin{array}{l}\text { Low-valine and } \\
\text { high-carbohydrate diets, } \\
\text { antioxidants (co-enzyme Q10, } \\
\text { vitamin E, vitamin C), carnitine, } \\
\text { and N-acetylcysteine [59] }\end{array}$ \\
\hline
\end{tabular}

\section{Non-Pharmacological Treatment of Epilepsy in Patients with Mitochondrial Disease}

An alternative treatment for epilepsy, aside from standard antiepileptic drugs, is a ketogenic diet (KD). This is a verified and recommended procedure both in adults and children, including infants [60-63]. There are reports of successful epilepsy treatment with a ketogenic diet in MD patients, especially those with impaired complex I of the mitochondrial respiratory chain [21,64]. A ketogenic diet is based on the supply of small amounts of carbohydrates to the benefit of fats. This leads to the formation of ketone bodies, which represent an alternative source of energy for cells. The antiepileptic mechanism of $\mathrm{KD}$ involves a reduction in the glutamate level in the sympathetic space, which reduces neuronal excitation.

Additionally, decanoic acid present in $\mathrm{KD}$ is a strong direct receptor inhibitor for glutamine- $\alpha$-amino-3-hydroxy-5-methyl-4-isoxazolepropionic acid receptor (AMPA) which directly translates into reduced neuronal excitation. An additional benefit, especially for MD patients, is that ketone bodies are a source of energy [13]. Although the mechanism of action of KD in MD patients is not fully explained, it is known to improve the cell energy profile, lead to the stimulation of mitochondrial biogenesis in skeletal muscles, prevent the 
formation of abnormal mitochondria, increase ATP production in the respiratory chain, and reduce the number of COX-negative fibres (a marker of mitochondrial damage) in skeletal muscle biopsy [65-67].

Numerous studies confirmed KD efficacy in patients with mitochondrial disease (both in adults and children), mainly concerning reducing epileptic seizures. One showed remission of epileptic seizures in 50\% of patients (12/24) treated with a KD [21]. Moreover, other studies showed that aside from better seizure control (seizure reduction $>50 \%$ in $8 / 20$ patients after one year and 7/20 patients after two years of a KD), all patients showed improvement in cognitive functions [68]. A KD may also improve muscular strength and reduce mtDNA heteroplasmy [67].

Other options for epilepsy treatment, especially in the case of refractory epilepsy, are vagal stimulation, deep brain stimulation, or palliative surgical treatment [26]. There are few literature data on the use of these approaches to treat epilepsy in patients with MD. VNS implantation was effective in two patients, resulting in a reduction in seizures of $>50 \%$ [9]. Palliative neurosurgical treatment was described in 4/40 patients with MD and Lennox-Gastaut syndrome [20].

\section{Prognosis in Epilepsy in Patients with Mitochondrial Disease}

Persistent seizures and status epilepticus lead to neural damage, astrocyte gliosis, damage to myelin, and, as a result, brain atrophy [5]. As confirmed by neuroimaging in subjects with MD and epilepsy, this group more often showed brain atrophy than those with MD and without epilepsy [36,69]. The occurrence of seizures in children is related to a worse prognosis regarding development and survival, especially if epilepsy occured at $<1$ year. Seizures are often intractable, and epilepsy leads to progressive neurodegenerative changes and epileptic encephalopathy $[6,9,20]$. In a group of 56 paediatric patients with MD, 45\% (22/56) of patients died, including half of the patients within nine months of the first seizure [33]. In another study, in a group of 46 children with MD and epilepsy, 11 children died within one year of the occurrence of epilepsy [69].

\section{Conclusions}

The mechanism of epilepsy development in mitochondrial diseases is a subject of ongoing studies, while the treatment of epilepsy is challenging for both physicians and scientists. Current studies, primarily involving multi-omic analyses, provide a better understanding of the mechanism leading to the development of such changes, which gives a chance for future detailed diagnostics and knowledge of impaired metabolic pathways, and, most of all, gives hope for the development of individualised treatment of patients $[2,70,71]$.

Author Contributions: Conceptualization, D.W.-K., D.R. and A.J.-S.; methodology, D.W.-K. and A.J.-S.; software, A.J-S.; validation, D.W.-K., D.R., A.J.-S.; formal analysis, D.W.-K; investigation, D.W-K.; re-sources, A.J.-S.; data curation, D.W.-K.; writing-original draft preparation, D.W.-K.; writing-review and editing, D.W.-K. and A.J.-S.; visualization, D.W.-K. and A.J.-S.; supervision, A.J.-S.; project administration, D.W.-K. and A.J.-S. All authors have read and agreed to the published version of the manuscript.

Funding: This research received no external funding.

Institutional Review Board Statement: Not applicable.

Informed Consent Statement: Not applicable.

Data Availability Statement: Not applicable.

Conflicts of Interest: The authors declare no conflict of interest. 


\section{References}

1. Rahman, S. Pathophysiology of mitochondrial disease causing epilepsy and status epilepticus. Epilepsy Behav. 2015, 49, 71-75. [CrossRef]

2. Stenton, S.L.; Prokisch, H. Genetics of mitochondrial diseases: Identifying mutations to help diagnosis. EBioMedicine 2020, 56, 102784. [CrossRef]

3. Tan, J.; Wagner, M.; Stenton, S.L.; Strom, T.M.; Wortmann, S.B.; Prokisch, H.; Meitinger, T.; Oexle, K.; Klopstock, T. Lifetime risk of autosomal recessive mitochondrial disorders calculated from genetic databases. EBioMedicine 2020, 54, 102730. [CrossRef]

4. Davison, J.E.; Rahman, S. Recognition, investigation and management of mitochondrial disease. Arch. Dis. Child. 2017, 102, 1082-1090. [CrossRef]

5. Alston, C.L.; Rocha, M.C.; Lax, N.Z.; Turnbull, D.M.; Taylor, R.W. The genetics and pathology of mitochondrial disease. J. Pathol. 2017, 241, 236-250. [CrossRef]

6. Lim, A.; Thomas, R.H. The mitochondrial epilepsies. Eur. J. Paediatr. Neurol. 2020, 24, 47-52. [CrossRef] [PubMed]

7. Coelho, M.P.; Martins, E.; Vilarinho, L. Diagnosis, management, and follow-up of mitochondrial disorders in childhood: A personalized medicine in the new era of genome sequence. Eur. J. Pediatr. 2019, 178, 21-32. [CrossRef] [PubMed]

8. Matricardi, S.; Canafoglia, L.; Ardissone, A.; Moroni, I.; Ragona, F.; Ghezzi, D.; Lamantea, E.; Nardocci, N.; Franceschetti, S.; Granata, T. Epileptic phenotypes in children with early-onset mitochondrial diseases. Acta Neurol. Scand. 2019, 140, 184-193. [CrossRef]

9. Khurana, D.S.; Salganicoff, L.; Melvin, J.J.; Hobdell, I.; Valencia, H.H.; Hardison, H.G.; Marks, W.D.; Grover, A.; Legido, A. Epilepsy and respiratory chain defects in children with mitochondrial encephalopathies. Neuropediatrics 2008, 39, 8-13. [CrossRef] [PubMed]

10. Ticci, C.; Sicca, F.; Ardissone, A.; Bertini, E.; Carelli, V.; Diodato, D.; Di Vito, L.; Filosto, M.; La Morgia, C.; Lamperti, C.; et al. Mitochondrial epilepsy: A cross-sectional nationwide Italian survey. Neurogenetics 2020, 21, 87-96. [CrossRef]

11. Fisher, R.S.; Cross, J.H.; French, J.A.; Higurashi, N.; Hirsch, E.; Jansen, F.E.; Lagae, L.; Moshé, S.L.; Peltola, J.; Roulet Perez, E.; et al. Operational classification of seizure types by the International League against Epilepsy: Position Paper of the ILAE Commission for Classification and Terminology. Epilepsia 2017, 58, 522-530. [CrossRef]

12. Iizuka, T.; Saka, F.; Suzuki, N.; Hata, T.; Tsukahara, S.; Fukuda, M.; Takiyama, Y. Neuronal hyperexcitability in stroke-like episodes of MELAS syndrome. Neurology 2002, 59, 816-824. [CrossRef] [PubMed]

13. Fei, Y.; Shi, R.; Song, Z.; Wu, J. Metabolic Control of Epilepsy: A Promising Therapeutic Target for Epilepsy. Front. Neurol. 2020, 11, 592514. [CrossRef] [PubMed]

14. Lax, N.Z.; Grady, J.; Laude, A.; Chan, F.; Hepplewhite, P.D.; Gorman, G.; Whittaker, R.G.; Ng, Y.; Cunningham, M.O.; Turnbull, D.M. Extensive respiratory chain defects in inhibitory interneurones in patients with mitochondrial disease. Neuropathol. Appl. Neurobiol. 2016, 42, 180-193. [CrossRef] [PubMed]

15. Bindoff, L.A.; Engelsen, B.A. Mitochondrial diseases and epilepsy. Epilepsia 2012, 53 (Suppl. S4), 92-97. [CrossRef]

16. Sanganahalli, B.G.; Herman, P.; Hyder, F.; Kannurpatti, S.S. Mitochondrial calcium uptake capacity modulates neocortical excitability. J. Cereb. Blood Flow Metab. 2013, 33, 1115-1126. [CrossRef]

17. Hardie, D.G.; Ross, F.A.; Hawley, S.A. AMPK: A nutrient and energy sensor that maintains energy homeostasis. Nat. Rev. Mol. Cell Biol. 2012, 13, 251-262. [CrossRef]

18. Bhandary, S.; Aguan, K. Pyruvate dehydrogenase complex deficiency and its relationship with epilepsy frequency-An overview. Epilepsy Res. 2015, 116, 40-52. [CrossRef]

19. Tranah, G.J.; Katzman, S.M.; Lauterjung, K.; Yaffe, K.; Manini, T.M.; Kritchevsky, S.; Newman, A.B.; Harris, T.B.; Cummings, S.R. Mitochondrial DNA m.3243A $>$ G heteroplasmy affects multiple aging phenotypes and risk of mortality. Sci. Rep. 2018, 8, 11887. [CrossRef]

20. Lee, S.; Baek, M.S.; Lee, Y.M. Lennox-Gastaut Syndrome in Mitochondrial Disease. Yonsei. Med. J. 2019, 60, 106-114. [CrossRef]

21. Lee, Y.M.; Kang, H.C.; Lee, J.S.; Kim, S.H.; Kim, E.Y.; Lee, S.K.; Slama, A.; Kim, H.D. Mitochondrial respiratory chain defects: Underlying etiology in various epileptic conditions. Epilepsia 2008, 49, 685-690. [CrossRef] [PubMed]

22. Whittaker, R.G.; Devine, H.E.; Gorman, G.S.; Schaefer, A.M.; Horvath, R.; Ng, Y.; Nesbitt, V.; Lax, N.Z.; McFarland, R.; Cunningham, M.O.; et al. Epilepsy in adults with mitochondrial disease: A cohort study. Ann. Neurol. 2015, 78, 949-957. [CrossRef]

23. Rahman, S. Mitochondrial disease andepilepsy. Dev. Med. Child Neurol. 2012, 54, 397-406. [CrossRef] [PubMed]

24. Pickett, S.J.; Grady, J.P.; Ng, Y.S.; Gorman, G.S.; Schaefer, A.M.; Wilson, I.J.; Cordell, H.J.; Turnbull, D.M.; Taylor, R.W.; McFarland, R. Phenotypic heterogeneity in m.3243A>G mitochondrial disease: The role of nuclear factors. Ann. Clin. Transl. Neurol. 2018, 5, 333-345. [CrossRef]

25. Hikmat, O.; Naess, K.; Engvall, M.; Klingenberg, C.; Rasmussen, M.; Tallaksen, C.M.; Brodtkorb, E.; Ostergaard, E.; de Coo, I.F.M.; Pias-Peleteiro, L.; et al. Simplifying the clinical classification of polymerase gamma (POLG) disease based on age of onset; studies using a cohort of 155 cases. J. Inherit. Metab. Dis. 2020, 43, 726-736. [CrossRef]

26. Rahman, S. Mitochondrial diseases and status epilepticus. Epilepsia 2018, 59 (Suppl. S2), 70-77. [CrossRef] [PubMed]

27. Patel, K.P.; O’Brien, T.W.; Subramony, S.H.; Shuster, J.; Stacpoole, P.W. The spectrum of pyruvate dehydrogenase complex deficiency: Clinical, biochemical and genetic features in 371 patients. Mol. Genet. Metab. 2012, 105, 34-43. [CrossRef] 
28. Ciara, E.; Rokicki, D.; Halat, P.; Karkucińska-Więckowska, A.; Piekutowska-Abramczuk, D.; Mayr, J.; Trubicka, J.; SzymańskaDębińska, T.; Pronicki, M.; Pajdowska, M.; et al. Difficulties in recognition of pyruvate dehydrogenase complex deficiency on the basis of clinical and biochemical features. The role of next-generation sequencing. Mol. Genet. Metab. Rep. 2016, 18, 70-76. [CrossRef]

29. Chang, X.; Wu, Y.; Zhou, J.; Meng, H.; Zhang, W.; Guo, J. A meta-analysis and systematic review of Leigh syndrome: Clinical manifestations respiratory chain enzyme complex deficiency, and gene mutations. Medicine 2020, 99, e18634. [CrossRef]

30. Horvath, R.; Chinnery, P.F. Diagnostic approach to mitochondrial diseases. In Diagnosis and Management of Mitochondria Disorders; Mancuso, M., Klostock, T., Eds.; Springer: Berlin/Heidelberg, Germany, 2019; pp. 281-287.

31. Lamperti, C.; Zeviani, M. Myoclonus epilepsy in mitochondria disorders. Epileptic Disord. 2016, 18, 94-102.

32. El-Hattab, A.W.; Adesina, A.M.; Jones, J.; Scaglia, F. MELAS syndrome: Clinical manifestations, pathogenesis and treatment options. Mol. Genet. Metabol. 2015, 116, 4-12. [CrossRef]

33. El Sabbagh, S.; Lebre, A.S.; Bahi-Buisson, N.; Delonlay, P.; Soufflet, C.; Boddaert, N.; Rio, M.; Rötig, A.; Dulac, O.; Munnich, A.; et al. Epileptic phenotypes in children with respiratory chain disorders. Epilepsia 2010, 51, 1225-1235. [CrossRef]

34. Surana, S.; Rossor, T.; Hassell, J.; Boyd, S.; D’Arco, F.; Aylett, S.; Bhate, S.; Carr, L.; Das, K.; DeVile, C.; et al. Diagnostic algorithm for children presenting with epilepsia partialis continua. Epilepsia 2020, 61, 2224-2233. [CrossRef]

35. Finsterer, J. Pharmacotherapeutic management of epilepsy in MERRF syndrome. Expert Opin. Drug Metab. Toxicol. 2019, 20, 1289-1297. [CrossRef]

36. Lee, S.; Na, J.H.; Lee, Y.M. Epilepsy in Leigh Syndrome with Mitochondrial DNA Mutations. Front. Neurol. 2019, 10, 496. [CrossRef]

37. Chevallier, J.A.; Von Allmen, G.K.; Koenig, M.K. Seizure semiology and EEG findings in mitochondrial diseases. Epilepsia 2014, 55, 707-712. [CrossRef] [PubMed]

38. Tzoulis, C.; Engelsen, B.A.; Telstad, W.; Aasly, J.; Zeviani, M.; Winterthun, S.; Ferrari, G.; Aarseth, J.H.; Bindoff, L.A. The spectrum of clinical disease caused by the A467T and W748S POLG mutations: A study of 26 cases. Brain 2006, 129, 1685-1692. [CrossRef] [PubMed]

39. Parikh, S.; Goldstein, A.; Karaa, A.; Koenig, M.K.; Anselm, I.; Brunel-Guitton, C.; Christodoulou, J.; Cohen, B.H.; Dimmock, D.; Enns, G.M.; et al. Patient care standards for primary mitochondrial disease: A consensus statement from the Mitochondrial Medicine Society. Genet. Med. 2017, 19. [CrossRef] [PubMed]

40. Garone, C.; Viscom, C. Towards a therapy for mitochondrial disease: An update. Biochem. Soc. Trans. 2018, 46, 1247-1261. [CrossRef]

41. Almannai, M.; El-Hattab, A.W.; Ali, M.; Soler-Alfonso, C.; Scaglia, F. Clinical trials in mitochondrial disorders, an update. Mol. Genet. Metab. 2020, 131, 1-13. [CrossRef] [PubMed]

42. Tinker, R.; Lim, A.Z.; Stefanetti, R.; McFarland, R. Current and Emerging Clinical Treatment in Mitochondrial Disease. Mol. Diagn. Ther. 2021, 25, 181-206. [CrossRef] [PubMed]

43. Mitochondrial Disease Care Recommendations. Physiotherapy Guidance for People with Mitochondrial Disease. Available online: www.newcastle-mitochondria.com (accessed on 26 June 2019).

44. Rahman, S. Advances in the treatment of mitochondrial epilepsies. Epilepsy Behav. 2019, 101 Pt B, 106546. [CrossRef]

45. Su, L.J.; Wang, Y.L.; Han, T.; Qiao, S.; Zang, K.J.; Wu, H.K.; Su, Y.X.; Liu, L.L.; Liu, X.W. Antimyoclonic effect of levetiracetam and clonazepam combined treatment on myoclonic epilepsy with ragged-red fiber syndrome with m.8344A>G Mutation. Chin. Med. J. 2018, 131, 2433-2438. [CrossRef] [PubMed]

46. Santamarina, E.; Alpuente, A.; Maisterra, O.; Sueiras, M.; Sarria, S.; Guzman, L.; Abraira, L.; Salas-Puig, J.; Toledo, M. Perampanel: A therapeutic alternative in refractory status epilepticus associated with MELAS syndrome. Epilepsy Behav. Case Rep. 2019, 11, 92-95. [CrossRef] [PubMed]

47. De Vries, M.C.; Brown, D.A.; Allen, M.E.; Bindoff, L.; Gorman, G.S.; Karaa, A.; Keshavan, N.; Lamperti, C.; McFarland, R.; Ng, Y.S.; et al. Safety of drug use in patients with a primary mitochondrial disease: An international Delphi-based consensus. J. Inherit. Metab. Dis. 2020, 43, 800-818. [CrossRef] [PubMed]

48. Parikh, S.; Goldstein, A.; Koenig, M.K.; Scaglia, F.; Enns, G.M.; Saneto, R.; Anselm, I.; Cohent, B.H.; Falk, M.J.; Greene, C.; et al. Diagnosis and management of mitochondrial disease: A consensus statement from the Mitochondrial Medicine Society. Genet. Med. 2015, 17, 689-701. [CrossRef]

49. Saneto, R.P.; Lee, I.C.; Koenig, M.K.; Bao, X.; Weng, S.W.; Naviaux, R.K.; Wong, L.J. POLG DNA testing as an emerging standard of care before instituting valproic acid therapy for pediatric seizure disorders. Seizure 2010, 19, 140-146. [CrossRef]

50. Finsterer, J. Toxicity of Antiepileptic Drugs to Mitochondria. Handb. Exp. Pharmacol. 2017, 240, 473-488.

51. Gruosso, F.; Montano, V.; Simoncini, C.; Siciliano, G.; Mancuso, M. Therapeutical Management and Drug Safety in Mitochondrial Diseases-Update 2020. J. Clin. Med. 2020, 10, 94. [CrossRef]

52. Koga, Y.; Nishioka, Y.; Nishioka, J.; Yatsuga, S.; Povalko, N.; Katayama, K.; Matsuishi, T. MELAS and L-arginine therapy. Mitochondrion 2007, 7, 133-139. [CrossRef] [PubMed]

53. Pineda, M.; Ormazabal, A.; Lopez-Gallardo, E.; Nascimento, A.; Solano, A.; Herrero, M.D.; Vilaseca, M.A.; Briones, P.; Ibáñez, L.; Montoya, J.; et al. Cerebral folate deficiency and leukoencephalopathy caused by a mitochondrial DNA deletion. Ann. Neurol. 2006, 59, 394-398. [CrossRef] [PubMed] 
54. Salviati, L.; Trevisson, E.; Doimo, M.; Navas, P. Primary Coenzyme Q10 Deficiency. In GeneReviews®[Internet], 1993-2020; Adam, M.P., Ardinger, H.H., Pagon, R.A., Wallace, S.E., Bean, L.J.H., Mirzaa, G., Amemiya, A., Eds.; University of Washington: Seattle, WA, USA, 2017.

55. Repp, B.M.; Mastantuono, E.; Alston, C.L.; Schiff, M.; Haack, T.B.; Rötig, A.; Ardissone, A.; Lombès, A.; Catarino, C.B.; Diodato, D.; et al. Clinical, biochemical and genetic spectrum of 70 patients with ACAD9 deficiency: Is riboflavin supplementation effective? Orphanet J. Rare Dis. 2018, 13, 120. [CrossRef]

56. Marcé-Grau, A.; Martí-Sánchez, L.; Baide-Mairena, H.; rtigoza-Escobar, J.D.; Pérez-Dueñas, B. Genetic defects of thiamine transport and metabolism: A review of clinical phenotypes, genetics, and functional studies. J. Inherit. Metab. Dis. 2019, 42, 581-597. [CrossRef]

57. Dahlin, M.; Martin, D.A.; Hedlund, Z.; Jonsson, M.; von Döbeln, U.; Wedell, A. The ketogenic diet compensates for AGC1 deficiency and improves myelination. Epilepsia 2015, 56, e176-e181. [CrossRef]

58. Viscomi, C.; Burlina, A.B.; Dweikat, I.; Savoiardo, M.; Lamperti, C.; Hildebrandt, T.; Tiranti, V.; Zeviani, M. Combined treatment with oral metronidazole and $\mathrm{N}$-acetylcysteine is effective in ethylmalonic encephalopathy. Nat. Med. 2010, 16, 869-871. [CrossRef]

59. Yamada, K.; Naiki, M.; Hoshino, S.; Kitaura, Y.; Kondo, Y.; Nomura, N.; Kimura, R.; Fukushi, D.; Yamada, Y.; Shimozawa, N.; et al. Clinical and biochemical characterization of 3-hydroxyisobutyryl-CoA hydrolase (HIBCH) deficiency that causes Leigh-like disease and ketoacidosis. Mol. Genet. Metab. Rep. 2014, 16, 455-460. [CrossRef] [PubMed]

60. Wells, J.; Swaminathan, A.; Paseka, J.; Hanson, C. Efficacy and Safety of a Ketogenic Diet in Children and Adolescents with Refractory Epilepsy-A Review. Nutrients 2020, 17, 1809. [CrossRef]

61. Kossoff, E.H.; Zupec-Kania, B.A.; Auvin, S.; Ballaban-Gil, K.R.; Christina Bergqvist, A.G.; Blackford, R.; Buchhalter, J.R.; Caraballo, R.H.; Cross, J.H.; Dahlin, M.G.; et al. Optimal clinical management of children receiving dietary therapies for epilepsy: Updated recommendations of the International Ketogenic Diet Study Group. Epilepsia Open. 2018, 3, 175-192. [CrossRef]

62. van der Louw, E.; van den Hurk, D.; Neal, E.; Leiendecker, B.; Fitzsimmon, G.; Dority, L.; Thompson, L.; Marchió, M.; Dudzińska, M.; Dressler, A.; et al. Ketogenic diet guidelines for infants with refractory epilepsy. Eur. J. Paediatr. Neurol. 2016, 20, 798-809. [CrossRef] [PubMed]

63. Martin-McGill, K.J.; Bresnahan, R.; Levy, R.G.; Cooper, P.N. Ketogenic diets for drug-resistant epilepsy. Cochrane Database Syst. Rev. 2020, 6, 1903. [CrossRef]

64. Paleologou, E.; Ismayilova, N.; Kinali, M. Use of the Ketogenic Diet to Treat Intractable Epilepsy in Mitochondrial Disorders. J. Clin. Med. 2017, 6, 56. [CrossRef]

65. Geffroy, G.; Benyahia, R.; Frey, S.; Desquiret-Dumas, V.; Gueguen, N.; Bris, C.; Belal, S.; Inisan, A.; Renaud, A.; Chevrollier, A.; et al. The accumulation of assembly intermediates of the mitochondrial complex I matrix arm is reduced by limiting glucose uptake in a neuronal-like model of MELAS syndrome. Biochim. Biophys. Acta Mol. Basis Dis. 2018, 1864, 1596. [CrossRef]

66. Santra, S.; Gilkerson, R.W.; Davidson, M.; Schon, E.A. Ketogenic treatment reduces deleted mitochondrial DNAs in cultured human cells. Ann. Neurol. 2004, 56, 662-669. [CrossRef] [PubMed]

67. Ahola-Erkkila, S.; Carroll, C.J.; Peltola-Mjosund, K.; Tulkki, V.; Mattila, I.; Seppänen-Laakso, T.; Oresic, M.; Tyynismaa, H.; Suomalainen, A. Ketogenic diet slows down mitochondrial myopathy progression in mice. Hum. Mol. Genet. 2010, 19, 1974-1984. [CrossRef]

68. Na, J.H.; Kim, H.D.; Lee, Y.M. Effective and safe diet therapies for Lennox-Gastaut syndrome with mitochondrial dysfunction. Ther. Adv. Neurol. Disord. 2020, 6, 13. [CrossRef] [PubMed]

69. Lee, H.F.; Chi, C.S.; Tsai, C.R.; Chen, C.H. Epileptic seizures in infants and children with mitochondrial diseases. Pediatr. Neurol. 2011, 45, 169-174. [CrossRef] [PubMed]

70. Inak, G.; Rybak-Wolf, A.; Lisowski, P.; Pentimalli, T.M.; Jüttner, R.; Glažar, P.; Uppal, K.; Bottani, E.; Brunetti, D.; Secker, C.; et al. Defective metabolic programming impairs early neuronal morphogenesis in neural cultures and an organoid model of Leigh syndrome. Nat. Commun. 2021, 12, 1929. [CrossRef]

71. Khan, S.; Ince-Dunn, G.; Suomalainen, A.; Elo, L.L. Integrative omics approaches provide biological and clinical insights: Examples from mitochondrial diseases. J. Clin. Investig. 2020, 130, 20-28. [CrossRef] [PubMed] 